\title{
Hand, Foot and Mouth Disease in an Adult Man - a Case Report
}

\author{
Milan D. BJEKIĆ 1 \\ ${ }^{1}$ City Institute for Skin and Venereal Diseases, Belgrade, Republic of Serbia \\ ${ }^{*}$ Correspondence: Milan BJEKIĆ, E-mail: milinkovski@gmail.com
}

UDC 616.5-002.1-022

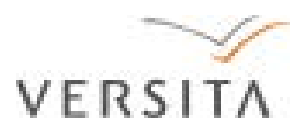

\begin{abstract}
Hand, foot and mouth disease is a systemic infection caused by enteroviruses. It is highly contagious, spreads by direct contact, and is commonly seen in young children. The disease is characterized by ulcerative oral lesions and a vesicular rash on palms, soles and characteristically between the fingers and toes, associated with mild systemic symptoms and signs such as fever and lymphadenopathy.

We present a 35-year-old man referred to a dermatologist with mouth lesions and skin rash. The patient had a fever, followed by a sore throat and malaise, which occurred two days before the rash. Physical examination revealed numerous superficial erosions and small vesicular lesions on the lower lip mucous membrane and on the hard palate, and also, multiple, discrete small vesicular lesions on fingers and toes. The patient was treated symptomatically and all the lesions resolved completely in a week. Adults with hand, foot and mouth disease usually experience milder symptoms than children. In conclusion: the disease should not be overlooked in middle-aged adults with a vesicular rash.
\end{abstract}

\section{Key words}

Hand, Foot and Mouth Disease; Adult; Enterovirus Infections; Signs and Symptoms; Treatment Outcome; Hyaluronic Acid

\begin{abstract}
lthough somewhat variable, the syndrome Aknown as hand, foot and mouth disease (HFMD) is characterized by a sudden outbreak of oral vesicles, which rapidly ulcerate and resemble those of herpangina, as well as skin lesions which are inconstant, but when present, particularly in children, may be characteristic and dominate the clinical picture: painful vesicles may appear, usually on the hands and/or feet, especially on the sides or backs of fingers and toes or at the base of the phalanges. Fever is usually mild and of short duration. The disease is caused by a group of enteroviruses, most commonly coxsackievirus A 16, and enterovirus 71 (1).

HFMD primarily affects children, although the infection occasionally occurs in adults. The disease is usually mild. The incubation period varies from three to ten days, and the symptoms usually subside within seven to ten days (2). HFMD is self-limiting and only rarely may be complicated by a systemic disease such
\end{abstract}

as encephalitis. The condition tends to be more severe when it occurs in adults (3).

\section{Case report}

A 35-year-old man was referred to a dermatologist with lesions in the mouth and a skin rash. The patient had a fever, followed by a sore throat and malaise, which occurred two days before the rash. Physical examination revealed numerous superficial erosions and small vesicular lesions on the mucous membrane of the lower lip (Figure 1.), on the hard palate, and also, multiple, discrete small vesicular lesions on fingers (Figure 2.) and toes (Figure 3.). The diagnosis was made based on the clinical history, as well as physical examination.

Laboratory findings, including complete blood count and blood chemistry were within normal limits. The patient was treated symptomatically with gingival hialuronic acid $0.2 \%$ gel, and his mucosal oral lesions completely resolved in a week. 


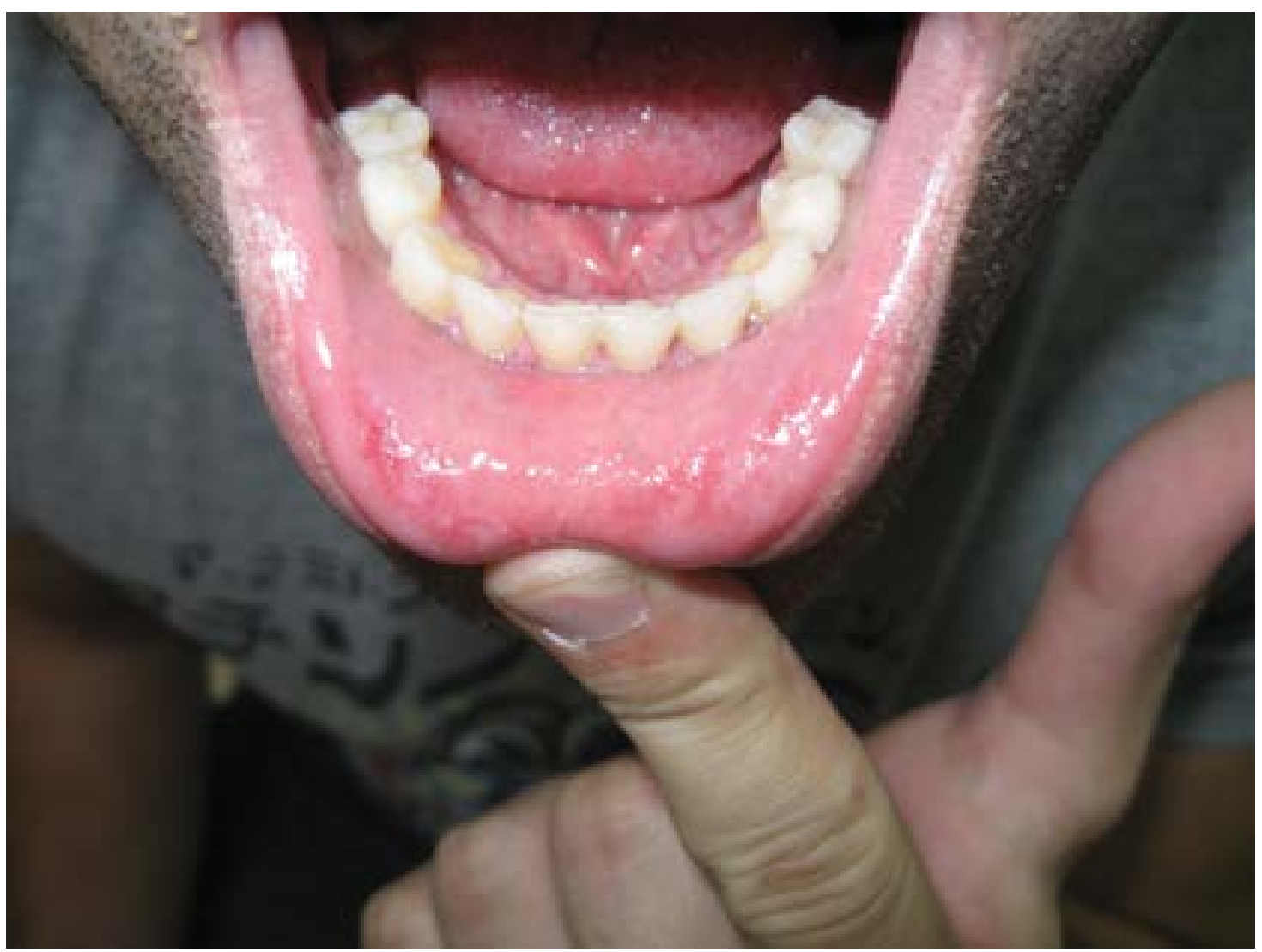

Figure 1. Multiple superficial erosions on the lower lip

\section{Discussion}

HFMD is a highly contagious disease, caused by one or several enteroviruses. The disease can be spread from person to person by contact with the saliva, respiratory secretions, vesicular fluid, as well as feces. The disease usually affects infants or young children, and epidemic outbreaks have occurred worldwide in the warmer months (4-8). HFMD has rarely been reported in immunocompetent adults (9).

Many infections are subclinical, but the most characteristic features of the syndrome include: fever, malaise, anorexia; slightly enlarged and tender anterior cervical lymph nodes; linear or oval, usually sparse oral ulcers which may affect any site; painful skin rash, sometimes deep-seated vesicles may appear, usually on the hands and/or feet, particularly on digits or at the base of the phalanges (10).

Following a brief prodrome of fever, sore throat and malaise, a characteristic enanthem and painful stomatitis develop, especially in adults (in children this may be mild). The oral vesicles which rapidly ulcerate resemble those of herpangina, but are rather larger and fewer in number and are irregularly distributed over the gums, buccal mucous membrane, palate, tongue and lips (Figure 1.). A skin rash develops over 1 - 2 days, as seen in our patient. It starts in a form of erythematous macules, evolving rapidly into thin-walled, pearly grey, oval or linear rather than rounded, small (up to $5 \mathrm{~mm}$ in diameter) vesicles with a red halo. The lesions are most frequently found on the hands they are usually located on the sides or backs of fingers and toes, especially around the nails, and around the margins of the heels, but may be seen in the finger flexures and on the palms and soles as in our case (Figures 2. and 3.). Lesions on the palms and soles are typically elliptical, with their long axis parallel to the skin lines (Figure 3.). More extensive papular or vesicular exanthem may develop, particularly in infants on the buttocks, but sometimes it is generalized (10).

A sudden outbreak of oral and distal extremity lesions is pathognomonic for HFMD. However, oral 


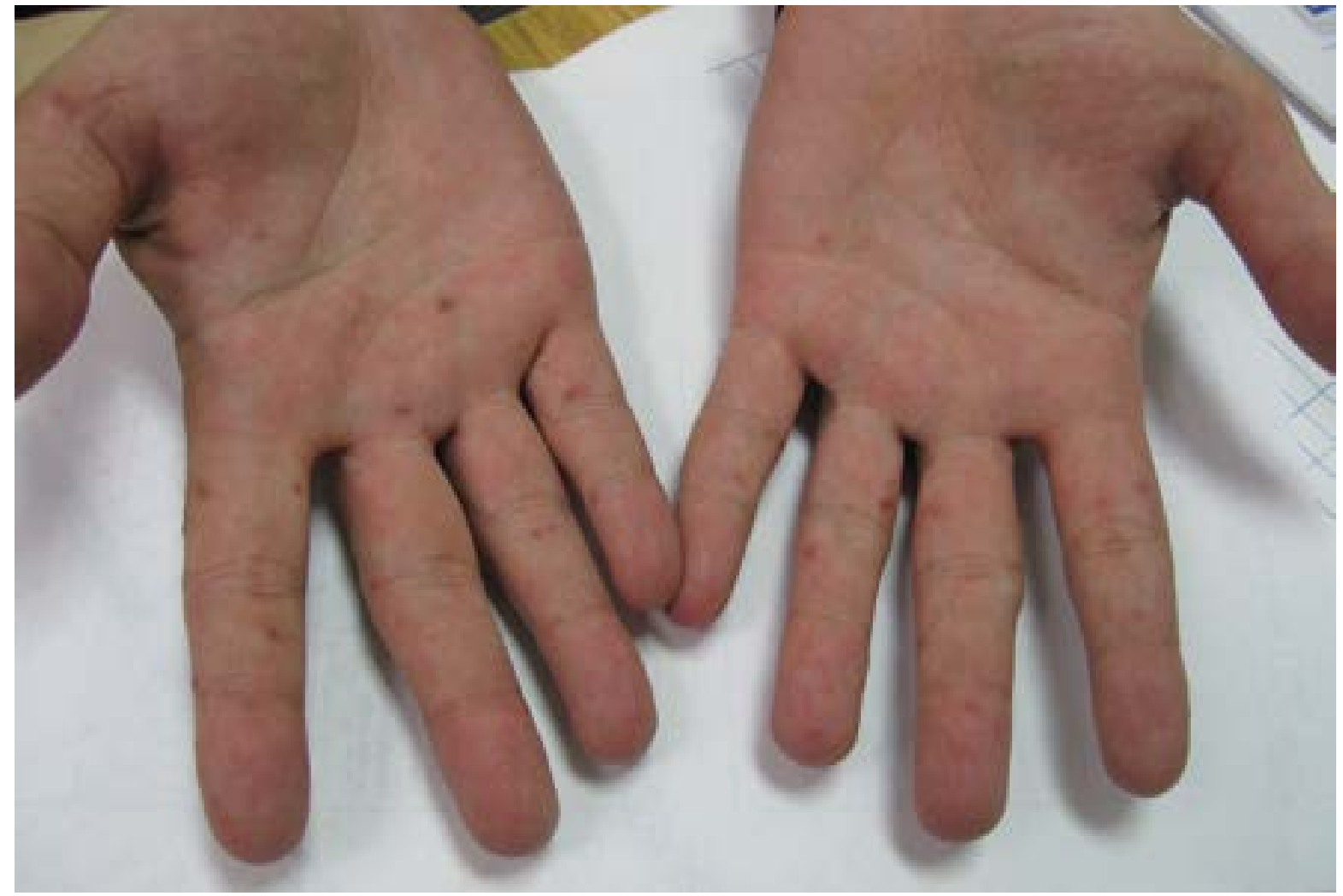

Figure 2. Small multiple erythematous macules on the fingers and palms

lesions may also occur without cutaneous lesions. Skin rashes have been reported in some other coxsackie syndromes, such as Gianotti-Crosti-like syndrome and erythema multiforme. As a rule, an exanthem in these and other coxsackie infections presents with few features to suggest the diagnosis, but the association with oral lesions should arouse suspicion. The differential diagnosis mostly includes herpes simplex stomatitis, chickenpox, vesicular stomatitis and foot and mouth disease (10).

Infection can be confirmed by isolation of the virus from the stool, vesicular fluid or nasopharynx, tissue culture or better in newborn mice, since only a few coxsackie A strains grow in tissue culture. Isolation from fecal samples alone may be misleading in the diagnosis of the disease, owing to the incidence of asymptomatic infections. Serology is of limited value, and slow, just like the culture, and the patient often recovers by the time the diagnosis is confirmed. Conventional histology either from biopsy or the scrappings from the base of blisters can be useful, but there is quite a high rate of false-negative results. Using an electron microscopy technique called negative staining technique, direct detection of virus particles in lesion samples can be achieved within half an hour. This technique has become invaluable in the confirmation of the diagnosis, mostly in lesions such as herpes simplex and zoster, and hand, foot and mouth disease (10). Unfortunately, as in our case, the technique is not widely available. HFMD is caused particularly by coxsackie A viruses, most frequently type 16 , less frequently types 4,5 , and 10 , but sometimes by coxsackie B viruses or enteroviruses, especially type 71. Coxsackie A strains (types 2, 3, 4, 5, 6, 8 and 10) and group B (type 3) cause herpangina. Herpangina is often found in cases with predominant features of hand, foot and mouth disease. Nevertheless, as with other enteroviruses, the clinical presentation caused by any of the strains is very variable (10).

The illness is usually mild and lasts only a few days, but severe complications such as pneumonia and myocarditis have been reported in adults (11). In our patient, lesions resolved after symptomatic treatment without complications. 


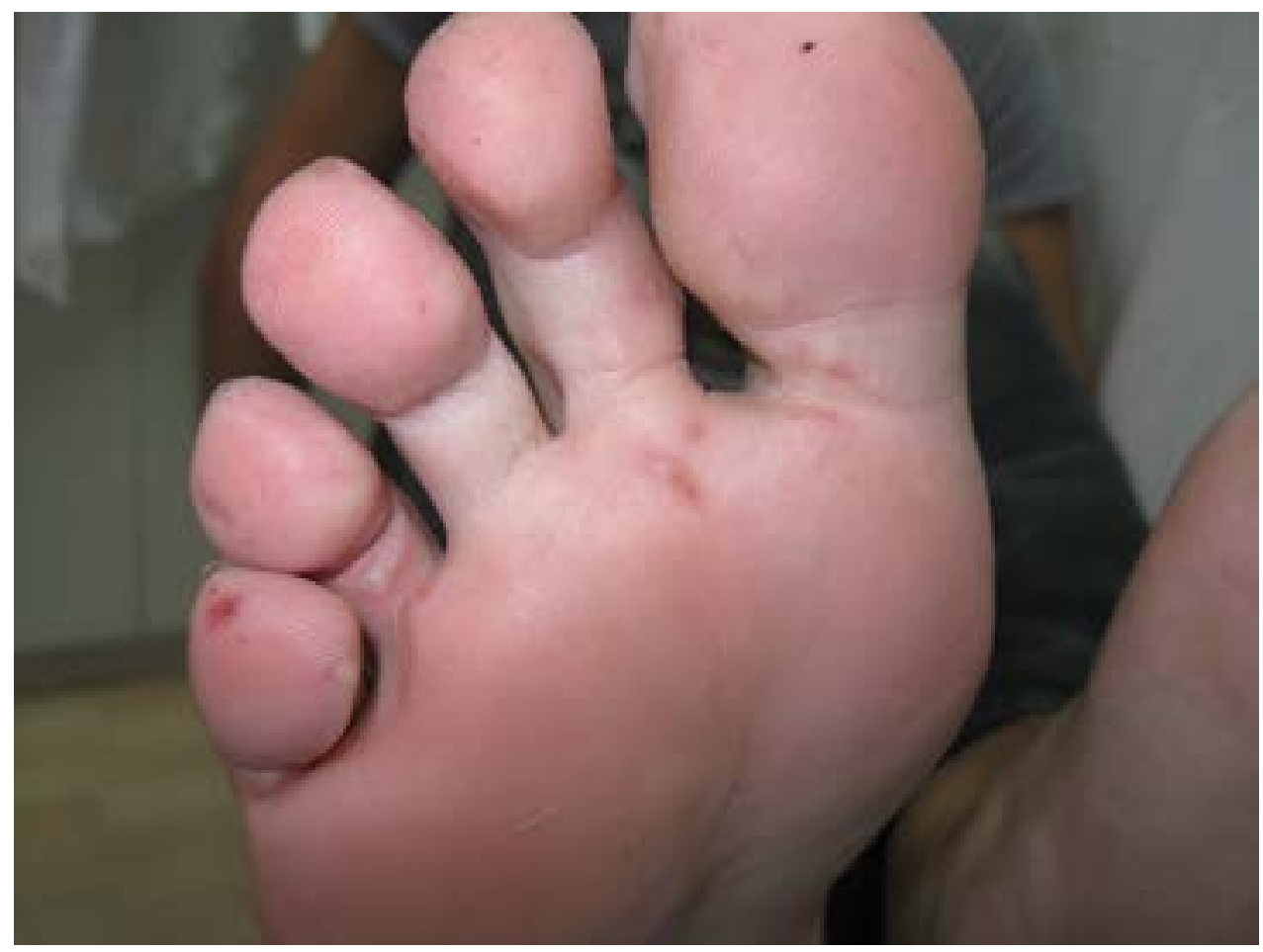

Figure 3. Vesicular lesions on the toes, with a characteristic linear shape

\section{Conclusion}

In conclusion, we report this case to remind physicians about the hand, foot and mouth disease, because the disease is rare in immunocompetent adults, and it should not be overlooked in middle-aged adults with vesicular rash. Because it is highly contagious, hygienic precautions are very important.

\section{Acknowledgement}

This study was supported by the Ministry of Science and Technology of the Republic of Serbia; Project No. $175402(2011-2014)$.

\section{Abbreviations}

HFMD - Hand, Foot and Mouth Disease

\section{References}

1. Li L, He Y, Yang H, Zhu J, Xu X, Dong J, et al. Genetic characteristics of human enterovirus 71 and Coxsackievirus A16 circulating from 1999 to 2004 in Shenzhen, People's Republic of China. J Clin Microbiol 2005;43:3835-9.

2. Belazarian L, Lorenzo ME, Pace NC, Sweeney SM, Wiss KM. Exanthematous viral diseases. In: Wolff K, Goldsmith LA, Katz SI, Gilchrest BA, Paller AS, Leffel DJ, editors. Fitzpatrick's dermatology in general medicine. $7^{\text {th }}$ ed. New York: Mc Grawe-
Hill; 2008. p. 1851-72.

3. Calonje E. Histopathology of the skin: general principles. In: Burns T, Breathnach S, Cox N, Griffiths C, editors. Rook's textbook of dermatology. $6^{\text {th }}$ ed. Oxford: Blackwell Publishing Ltd; 2010. p. 10.1-43.

4. Wei SH, Huang YP, Liu MC, Tsou TP, Lin HC, Lin TL, et al. An outbreak of coxsackievirus A6 hand, foot, and mouth disease associated with onychomadesis in Taiwan, 2010. BMC Infect Dis 2011;11:346.

5. Wu Y, Yeo A, Phoon MC, Tan EL, Poh CL, Quak SH, et al. The largest outbreak of hand, foot and mouth disease in Singapore in 2008: the role of enterovirus 71 and coxsackievirus A strains. Int J Infect Dis 2010;14:e1076-81.

6. Rabenau HF, Richter M, Doerr HW. Hand, foot and mouth disease: seroprevalence of coxsackie A16 and enterovirus 71 in Germany. Med Microbiol Immunol 2010;199(1):45-51.

7. Blomqvist S, Klemola P, Kaijalainen S, Paananen A, Simonen ML, Vuorinen T, et al. Co-circulation of coxsackieviruses A6 and A10 in hand, foot and mouth disease outbreak in Finland. J Clin Virol 2010;48:49-54. 8. Bending JW, Fleming DM. Epidemiological, virological, and clinical features of an epidemic of hand, foot, and mouth disease in England and Wales. Commun Dis Rep CDR Rev 1996;6:R81-6.

9. Shin JU, Oh SH, Lee JH. A case of hand-foot-mouth disease in an immunocompetent adult. Ann Dermatol 2010;22:216-8. 10. Sterling JC. Virus infections. In: Burns T, Breathnach S, Cox N, Griffiths C, editors. Rook's textbook of dermatology. $6^{\text {th }}$ ed. Oxford: Blackwell Publishing Ltd; 2010. p. 33.1-81.

11. Baker DA, Philips CA. Fatal hand-foot-and-mouth disease in an adult caused by coxsackievirus 47. JAMA 1979;242:1065 


\section{Bolest stopala, šaka i usta kod odraslih - prikaz slučaja}

\section{Sažetak}

Uvod: Bolest šaka, stopala i usta je veoma kontagiozna sistemska infekcija izazvana enterovirusima koja se najčešće javlja kod dece. Oboljenje najčešće izaziva koksaki virus A16 i enterovirus 71. Karakteriše ga pojava vezikula na orofaringealnoj sluznici koje brzo prskaju ostavljajući bolne erozije i ospa na koži distalnih delova ekstremiteta, najčešće šaka i stopala. Obično se javlja blag poremećaj opšteg stanja.

Prikaz slučaja: Prikazujemo pacijenta starog 35 godina koji je došao kod dermatologa zbog ranica u usnoj duplji i osipa po dlanovima i tabanima. Dva dana pre pojave ovih promena pacijent je imao povišenu temperaturu, malaksalost i gušobolju. Pregledom je utvrđeno prisustvo brojnih erozija na sluznici tvrdog nepca i donje usne, eritematoznih makula na dlanovima i tabanima i vezikula $\mathrm{u}$ interdigitalnim prostorima. Promene su se povukle uz simptomatsku terapiju.

Diskusija: Dok promene mogu zahvatiti bilo koji deo oralne sluznice, nepce, jezik ili usne (Slika 1), karakterističan je izgled i lokalizacija osipa po koži. Promene na koži su najčešće lokalizovane na bočnim i dorzalnim stranama prstiju dlanova i tabana, naročito oko nokatnih ploča ali se mogu videti i na prevojima falangealnih zglobova, dlanovima I tabanima (slike $2 \mathrm{i}$ 3). Vezikule su sitne, sivobeličaste boje karakterističnog ovalnog, linearnog, osnosno elipsastog oblika, sa dužom osovinom postavljenom paralelno sa funkcionalnim linijama kože (Slika 3). Kod dece osip može biti generalizovan: makulopapulozan ili papulovezikulozan.

Bolest šaka, stopala i usta se retko javlja kod odraslih osoba očuvanog imunostatusa.

Iznenadan atak oralnih i lezija na distalnim delovima ekstremiteta je patognomoničan, ali se oralne lezije mogu javiti i bez kutanih, što se neretko viđa u tzv. koksaki sindromima, Gianotti-Crosti-like sindromu i sindromu multiformnog eritema. Po pravilu, osip koji se javlja u toku ovih sindroma, obično nije dijagnostički punovredan, ukoliko nije zahvaćena orofaringealna sluznica. U diferencijalnoj dijagnozi treba isključiti stomatitis izazvan herpes simpleks virusom, vezikulozni stomatitis, varicelu i bolest stopala i usta.

Infekcija se dokazuje izolacijom virusa iz sadržaja vezikula ili nazofarinksa, u tkivnoj kulturi ili bolje inokulacijom u eksperimentalne životinje $s$ obzirom da samo mali broj koksaki virusa iz grupe A raste $\mathrm{u}$ kulturi tkiva. Izolacija virusa isključivo iz fecesa nema dijagnostički značaj s obzirom na visoku učestalost infekcija bez simptoma. Serološka dijagnostika je od ograničenog značaja kao i kultura, naročito ako se uzme u obzir vreme za koje isti pružaju pozitivan nalaz. Konvencionalna histološka analiza bioptiranog uzorka ili skarifikata dna vezikule može imati dijagnostičku vrednost ali pruža veliki procenat lažnonegativnih rezultata. Direktno dokazivanje virusnih partikula u ispitivanom uzorku pomoću elektronskog mikroskopa, tehnikom tzv. negativnog bojenja, omogućuje postavljanje dijagnoze u roku od pola časa. Ova tehnika ima neprocenjiv dijagnostički značaj kod mnogih virusnih oboljenja a naročito kod infekcija izazvanim herpes simpleks i zoster virusima i kod bolesti šaka, stopala i usta. Nažalost, ova metoda nije uvek dostupna što je bio slučaj i kod našeg pacijenta. U najvećem broju slučajeva bolest izaziva koksaki virus A16, ređe A4, A5, A10, a ponekad tipovi iz grupe B, i enterovirusi - naročito tip 71 .

Herpanginu izazivaju koksaki A virusi (tipovi 2, 3, 4, 5 , 6, 8 i 10) i koksaki B virus tip 3. Neretko, herpangina prati bolest šaka, stopala i usta. Kao što je slučaj i sa ostalim enterovirusnim infekcijama, klinički sindromi izazvani bilo kojim pojedinim tipom pokazuju veliku kliničku varijabilnost.

Bolest je obično blagog toka i traje nekoliko dana, kao kod našeg pacijenta. Iako retko, moguća je pojava teških komplikacija, pneumonije, miokarditisa i encefalitisa.

Zaključak: Bolest šaka, stopala i usta kod odraslih osoba je obično blažeg toka nego kod dece. Zbog infektivnosti oboljenja ovaj karakteristični osip ne bi trebalo ni kod njih prevideti

\section{Ključne reči}

Bolest šaka, stopala i usta; Odrasli; Enterovirusne infekcije; Znaci i simptomi; Ishod lečenja; Hijaluronska kiselina 